\title{
Developing a Typology of Diaspora Tourists: Return Travel by Chinese Immigrants in North America
}

\author{
Tingting Elle Li* \\ Middlesex University London, Hendon Campus \\ E-mail: t.li@mdx.ac.uk
}

Bob McKercher

School of Hotel and Tourism Management, The Hong Kong Polytechnic University Bob.Mckercher@polyu.edu.hk

For citation use: Li, T. E., \& McKercher, B. (2016). Developing a typology of diaspora tourists: Return travel by Chinese immigrants in North America. Tourism Management, $56,106-113$.

*Corresponding author 


\begin{abstract}
This paper examines the role played by tourism in affecting cultural identity and place attachment among members of the North American Chinese diaspora who travel to China. Previous literature portrays diaspora tourists as homogeneous and suggests that home return travel engenders broadly similar impacts on the individual. This study reveals diasporic communities are quite diverse and complex. Five types of diaspora tourist are identified, each having distinct travel motives, experiences, migration backgrounds, cultural identities and place attachments. The consequences of diaspora tourism particularly in terms of place attachment and cultural identity are further discussed, as home return travel induces positive, neutral and negative reactions.
\end{abstract}

Key words: Diasporic travel, Place attachment, Cultural identity, Migration, Chinese diaspora

\title{
1. Introduction
}

Research on travel by members of diasporic communities can be found under many names including home return travel (Duval, 2004; Basu, 2007; Kang \& Page, 2000; Nguyen \& King, 2004; Hughes \& Allen, 2010; Pearce, 2012), roots tourism (Bruner, 1996; 
Basu, 2005; Handley, 2006; Pinho, 2008), ethnic tourism (Ostrowski, 1991; Kang \& Page, 2000; Butler, 2003; Fourie \& Santana-Gallego, 2013), visiting friends and relatives (VFR) tourism (Uriely, 2010; Pearce, 2012), genealogical tourism (Santos \& Yan, 2010) and of course diaspora (diasporic) travel (Kim \& Stodolska, 2013) or tourism (Coles \& Timothy, 2004; Moufakkir, 2011). Importantly, with few notable exceptions (Coles \& Timothy, 2004), these types of studies tend to regard diasporic groups as being undifferentiated, and who, depending on the group in question, travel for similar reasons and achieve broadly similar outcomes associated with resolving personal identity conflicts, discovering one's roots, retaining or maintaining personal connections or engendering feelings of being at home in their "native" soil (Duval, 2004; Stephenson, 2002; Timothy, 2008; Wessendorf, 2007). With the exception of roots tourism conducted by descendants of former slaves (Handley, 2006; Pinho, 2008) and a few studies on multi-generation migrants (Wessendorf, 2007; Coles \& Timothy, 2004), most of current research tends to focus on recent migrants from a single ethnic group who have moved to a single migrant destination (Hughes \& Allen, 2010; Fourie \& Santana-Gallego, 2013; Kim \& Stodolska, 2013).

While this literature is informative at one level, it largely fails to appreciate that diasporic communities, like all populations, are heterogeneous. Members migrated at different times, sometimes many generations earlier, had different reasons to migrate and have or retain different levels of connection to both their country of origin and their current country of residence. These conditions influence place attachment and cultural identity. Some identify themselves as belonging to their migrant country, others retain a strong sense of identity with their country of origin, others feel comfortable in both worlds and others still may feel rootless (McHugh \& Mings, 1996). As such, one would expect the reasons to engage in travel back to one's ancestral home vary as would their subsequent experiences. Some travel to ancestral home for deep reasons of seeking roots and feeling connected to one's ancestry (Basu, 2005), and the others return for leisure and business purposes (Reynolds, 2010).

This research examines the travel back to China by members of the North American Chinese diasporic community. Its focus is on migrants whose original roots are mainland China and not in other ethnic Chinese economies such as Hong Kong, Singapore, Macao, Taiwan, Vietnam and the like. Chinese has a long migration history and growing prevalence. Chinese traditional value appreciates home and ancestry and has driven 
growing number of individuals with Chinese heritage to trace their ancestry (Mei et al., 2001). The study explores how travel experience affects diaspora tourists by looking at whether return travel stretches or further embeds ties to either North America or China, reduces ties to either place, or strengthens mixed place identity. In the end, a typology of diaspora tourists is proposed.

\section{Research context}

The word "diaspora" has been used traditionally to describe populations "deterritorialized" and "transnational" in nature and whose economic, social and political networks cross state borders (Vertovec, 1999; Safran, 1991). Diasporic members in first-generation may maintain a stronger attachment to ancestry homeland, such that their identities are not yet completely transformed (Hay, 1998). Once generations have passed, the descendants from families with long history of migration have better assimilated to the host society and have become important actor in the construction of national narratives, regional fusion and transnational political economies (Vertovec, 1999). Significant changes occur in place attachment and identities and their ties may not be as strong as those experienced by their ancestors. This would lead to difficulties with self-identity as they question who they are and where their genuine home is.

\subsection{The Chinese diaspora}

The Chinese have a long migration history to the West (Pan, 1994), with three key migration waves noted: the Gold Rush (1840-1900), Post World War II/Post China Civil War (1945-1978) and Post Open-Door Policy (1979-present) (Wang \& Lo, 2005; Tan, 2013; Lewis, 2009). North America has been a key destination for migrants from Southern China since the mid-1800s (Light, 1984; Daniels, 1990), when more than 50,000 Chinese moved there during the California Gold Rush and subsequently worked on railway construction (Government of Canada, 2012). Most migrants at this time were single men, or married men who left their families behind. This wave continued until the late 1800s when the United States implemented the Chinese Exclusion Act in 1882, followed by similar legislation introduced in Canada some years later (Kemp \& Chang, 2004) that imposed strict restrictions on Chinese migration. The result was an effective cessation of migration until well after the Second World War (Lee, 2003), leaving remnant Chinese populations in Chinatowns. Here familiar linguistic and cultural environments 
helped maintain their lifestyles, traditions and culture (Pan, 1998).

A second wave occurred in the aftermath of the Chinese Civil War in the early 1950s. Many migrants were both political and economic refugees who initially left China temporarily, hoping to return once the political situation stabilized ( $\mathrm{Li}, 1998)$. Many also had multiple migration patterns, moving first to places like Hong Kong, Taiwan and Vietnam, often for many years before migrating permanently to North America when it became clear they could not return home (Con \& Wickberg, 1982; Chang, 2004). Many set down some roots in intermediate countries and had children there.

The third wave began with the introduction of China's Open Door Policy announced by Deng Xiaoping in 1978. This policy allowed citizens to move voluntarily to developed countries for a better life quality, employment opportunities and education. As a result, unlike in early eras, most Chinese immigrants could be classified as life-style migrants who had strong educational backgrounds (Skeldon, 1996). They also cared about the development of their motherland and strove to maintain their Chineseness after migration (Mei et al., 2001).

\subsection{Place and place attachment}

Place is a bounded entity with unique identity and historical continuity that involves three principal components of geographical location, material form and investment with meaning and value (Tuan, 1974; Gieryn, 2000). People-place bonding can consist of affective (emotion, feeling), cognitive (thought, knowledge, belief), and behavioral (action, behavior) dimensions (Williams et al., 1992). More recently, Scannell and Gifford (2010) suggested place attachment could be understood from the dimensions of person, place, and process. They defined the personal dimension by individual or collective meanings, the place dimension by characteristics of attachment associated with spatial specificity, and the prominence of social and physical elements in defining the space and the process dimension by the affective, cognitive, and behavioral components of attachment. Indeed, place attachment can be experienced at both individual and group level (Low \& Altman, 1992, Shamsuddin \& Ujang 2008), for group experiences and memories also play a role in determining the attachment an individual has to the place.

This issue is especially relevant for members of diasporic groups, for they often 
congregate (or were forced to congregate) in a relatively bounded space that ensured maintenance of common bonds of ethnicity, culture, religion, national identity and race (Cohen, 1997; Vertovec, 2001; Coles \& Timothy, 2004), and in doing so, also ensured their status as outsiders in the host community. On the one hand, it served the purpose of retaining a semblance of their home culture, language, identity and rootedness through generations (Vertovec, 2001). On the other hand, it also ensured they remained culturally apart from the host society even though they were physically a part of it. It must also be appreciated that the retention of their status as 'other' was often enforced by the dominant host culture especially when the other was ethnically (Berry, 1997), linguistically or culturally different (Hannerz, 1992; Berry \& Kalin, 1995; Berry, 2000), or if the receiving society held negative attitudes toward the diasporic members (Barry, 2000).

While common-sense understandings of place are more focused on stability and continuity than change, a number of studies has portrayed places and people-place bonding as being dynamic (Massey, 1994; Gieryn, 2000; Gustafson, 2006), meaning migrants often develop and/or retain multiple attachments to different places (McHugh \& Mings, 1996; Williams \& McIntyre, 2001; Beckley, 2003; Stedman, 2006; Wilson \& Peters, 2005). Some of the factors influencing the likelihood of multiple place attachments forming include: history of moves and age at which migration occurred (Bolan, 1997; Cuba \& Hummon, 1993); internal pressure from migrant communities to retain the ethnic, racial or religious purity (Werbner, 2004); the receptiveness of the new country to migrants (Berry, 2000); and the individual's own cultural identity (Jameson, 2007). Moreover, the degree of attachment can vary from the superficial to the deep depending on length of residence (Hay, 1998), strength of social ties (Ringel \& Finkelstein, 1991), and mobility (Gustafson, 2001). A complicating factor is people with mixed cultural backgrounds, for they may only have a vague awareness of their ancestral background and feel attached to their current place of residence (Chen, Benet-Martinez, \& Bond, 2008; Hollinshead, 2004; McHugh \& Mings, 1996; Williams \& McIntyre, 2001). Kearney (1995) notes further that, in some cases, self-identification as members of diasporic communities may fade after a few generations, while in other cases, it may be re-awakened leading to an enhanced sense of belonging to a diaspora community.

A few current studies (Gustafson, 2001, 2009; Van der Klis \& Karsten, 2009) in the place and diaspora literature argued that mobility in different forms can affect place 
bonding in various ways. Some may decrease place attachment (Gustafson, 2009), while some generally reinforces place attachment (Van der Klis \& Karsten, 2009). In the context of diaspora return travel, migrants with different identity backgrounds may experience more complex changes after their return. Individuals who retain a strong attachment to their place of origin could use travel as a means of reinforcing that bond (Kang \& Page, 2000), and some others may also find their ties loosening over time and feel less attached. Individuals who have a mixed sense of place could experience no change, stronger ties with ancestral homes, or stronger ties with the host country after their return. Similarly, those individuals who are strongly attached to their current place of residence could feel no change, a mix of ties to their current and ancestral homes, or feel single attachment to their ancestral home. With all these possibilities, this study aims to explore the impacts of diasporic return have on one's place attachment.

\subsection{Cultural identity}

How individuals and social groups negotiate their identities within transnational frameworks has become one of the core foci on studies of migration and culture (Vertovec, 2001). Hall (2000) defines the process of determining one's identity as identification and argues that identification is constructed on the back of recognition of some common origin or shared characteristics with another person or group, and with the natural closure of solidarity on this foundation. Likewise, Tajfel's (1981) theory of social identity reflects an individual's self-concept which derives from his knowledge of his membership in a social group (or groups) together with the value and emotional significance attached to the membership. To Sussman (2000) and Jameson (2007), the emphasis is on cultural identity as being part of the larger concept of collective identity that refers to an individual's sense of self derived from formal or informal membership in groups that transmit and inculcate knowledge, beliefs, values, attitudes, traditions, and ways of life. Although collective identity includes both cultural and social aspects, cultural identity emphasizes its close connection to family history, transmission of knowledge and values between generations.

Historically, the migration literature assumed immigrants would gradually lose their original identity and assume a new one as part of the process of assimilation (Castles, 2000; Gustafson, 2009). But, according to Davidson and Eng (2008), original identities begin to be challenged as soon as migrants land in host countries, with cultural identities morphing over time. It is for this reason first-generation migrants may maintain a strong 
attachment to their ancestral home (Hay, 1998), while over time and across generations, descendants become better assimilated to the host society (Vertovec, 1999) and hold different interpretations of their ancestral homes than more recent migrants.

\subsection{Diasporic travel}

Travelling to distant homelands may help members of diasporic communities evaluate themselves, resolve their personal identity conflicts, and connect with their predecessors (Timothy, 2008). The desire for sameness, continuity and a search for cultural footholds (Hollinshead, 2004; Wilson \& Dissanayake, 1996) is a common theme in much of the literature (Kang \& Page, 2000; Nguyen \& King, 2004; Hughes \& Allen, 2010; Uriely, 2010). Here return travel is seen to play an important role in maintaining cultural identity (Lew \& Wong, 2004; Duval, 2004), sustaining or creating connections to one's cultural roots (McCain \& Ray, 2003), discovering oneself (Franklin \& Crang, 2001) or helping resolve personal identity crisis (Basu, 2007; Marcus \& Fischer, 1986). The roots theme is especially strong among dispossessed diasporas or those who have a very distant and disassociated migration history. Basu (2007) illustrates descendants of slaves embark on something akin to a "pilgrimage" or "a journey of discovery" to seek their roots, identity, sense of home and belonging. Pinho (2008) also suggests these people have a strong aspiration to construct their identities, for many immigrants who have lost complete touch with their ancestral home are on a mythical quest. Cohen (1988), though, reminds us that the collective memories of these people's homeland may exist at a more romantic level and be far removed from the reality of the place today.

An alternate body of literature suggests the motives for diaspora travel may have more to do with a quest for the other and the desire to experience the "difference" and "change" to ancestral homelands (Van den Berghe, 1994; Stefansson, 2004; Richards, 2005). In some cases, a risk exists that such journeys may lead to confusion about identity as tourists realize the extent of their "outsideness" from their ancestral homes (Handley, 2006). Thus, it is the purpose of this article to investigate how diasporic return impacts on individuals' sense of place and cultural identity.

\section{Method}


A qualitative research design was adopted focusing on questions of "how" and "why" (Strauss \& Corbin, 1998) through exploring the process of how diaspora tourists' return affects their place attachment and why they have different experiences. The target respondents were different generations of Chinese living in North America who travelled to mainland China. Snowball sampling was used to approach candidates through several Chinese immigrant associations in the United States, Canada as well as Overseas Chinese Office in Jiangmen. Social networks of identified respondents were used to provide the researchers with an ever-expanding set of potential contacts (Atkinson \& Flint, 2001). The sample size was determined based on Kuzel's (1992) principle of "looking for disconfirming evidence or trying to achieve maximum variation" and the desire to be able to define possible categories of respondents, themes and explanations (Guest, Bunce, \& Johnson, 2006).

In order to ensure the trustworthiness of a qualitative study, the authors addressed credibility, transferability, dependability and confirmability based on the criteria developed by Lincoln and Guba (1985). First, a methodology design based on multiple data sources to achieve data validation and verification was adopted. The data collected through in-depth interviews were from different population in the United States, Canada and mainland China through multiple Chinese immigrant associations. Second, the research instrument including the interview guide and analysis system were checked by academic peers who were not participants of the study but belonged to part of overseas Chinese. Third, empirical evidence including data collection methods, the respondents' socio-demographic information, and the number and length of the data collection were provided to enable the reader to make a transfer. Finally, the research process was recorded to develop a thorough understanding of the methods and effectiveness for anyone interested in conducting similar study. Since there were two authors involved in this study, the codes consistency and reliability check were conducted through two authors' individual reviews, interactive and iterative discussion process (Boyatzis, 1998). Coding discrepancies were resolved by full discussion between authors while the unnecessary codes were reduced until arriving at the final typology discussed below. For instance, unnecessary code like "personal identity" was reduced and replaced by "pre-trip cultural identity" through full discussion process during consistency and reliability check.

Semi-structured interviews were conducted in four locations (Los Angeles, San 
Francisco, Vancouver and Jiangmen) with 46 individuals between February and October 2013. The interviews took place at the locales that the interviewees preferred, including their homes, association locales, cafes, etc. An interview guide was prepared based on the literature review and tested in prior to the fieldwork with potential respondents (Charmaz $\&$ Belgrave, 2002). The key question of how diasporic return affects place attachment and cultural identity helped develop the interview guide which finally consisted of five main sections: family migration history, personal identity, place attachment, home return visit, and post-return effects. Each interview lasted about one hour. The majority of the interviews were conducted in English, with some conducted in Cantonese or Mandarin. All of the interviews were recorded with the exception of one respondent who asked not to be recorded. For this particular interview, detailed notes were taken during interview and transcribed on the same day when memory was fresh. Names of interviewees have been changed to ensure confidentiality.

The sample consisted of 28 people from the United States and 18 from Canada. A total of 26 were first-generation Chinese migrants who were born in China or Hong Kong. The other 20 had a longer migration history ranging from the second to the sixth generations. More men (26) participated than women and their ages raged from 21 to 79 , and the majority of the interviewees were well-educated. Most (32) had made multiple return visits to their ancestral home communities. A further six had visited their ancestral home once, while the remaining eight had restricted their China travel to big cities and not their ancestral villages.

Qualitative content analysis was conducted for obtaining typologies, underlying understanding of themes and topics, along with the respondents' perceptions of how they understood themselves and the world, guided by protocols developed by Miles and Huberman (1994) and Hsieh and Shannon (2005). Interview transcripts and memorandum were prepared and revisited a number of times and a code schema was developed consisting of key themes derived from the interview. A two-step analysis process was undertaken. The first step categorized respondents based on their reported pre-trip cultural identity and the impact home return travel had on their place attachment. In this stage, the study team identified eight initial groups based on their cultural identity and change of place attachment. A second round of analysis further refined the groups into five types diaspora tourist. Group 1, 4 and 5 reported strong pre-trip Chinese identity and increased 
or stabilized strong Chinese attachment after the return trip, which fell into type 1. Group 2 reported mixed pre-trip identity and increased Chinese attachment after the return trip which lead to type 2. Group 3 with strong Western pre-trip identity reported having clearly increased Chinese attachment after their return trip which fell into type 3. Group 6 and 7 with strong Western pre-trip identity reported no significant change in place attachment after their return trip which were identified as type 4. Group eight who reported decreased sense of Chinese attachment was identified as type 5. Each of the five types is discussed in detail below.

Limitations in research design should be acknowledged. First, the concept of "ancestral home" was used at the macro level during communications with our interviewees. Several interviewees have not returned to their ancestral villages, but they considered their return visit(s) to other parts of China as "coming home" as well. Second, limitations relating to the representativeness of a snowball sample are acknowledged. Third, it was difficult to reach the members of older generations of diaspora, many of whom have successfully assimilated into the host society and may not feel belonging to those overseas Chinese associations. Thus, while five types of diaspora tourist are identified, no attempt is made to quantify the size of each segment.

\section{Findings}

Five discrete types of diaspora tourists were identified by considering cultural identity and post-travel impact on place attachment. The five groups have been labelled the: Re-affirmative, Quest, Reconnected, Distanced and Detached tourists. The characteristics of each type are shown in Table 1.

\section{Table 1}

Typology of diaspora tourist

\begin{tabular}{|l|l|l|l|l|l|}
\hline Type & Re-affirmative & Quest & Reconnected & Distanced & Detached \\
\hline Sample & 17 & 10 & 3 & 12 & 4 \\
\hline & $\begin{array}{l}\text { Identify as } \\
\text { Chinese; return } \\
\text { visit increases } \\
\text { /maintains } \\
\text { Chinese } \\
\text { attachment }\end{array}$ & $\begin{array}{l}\text { Identify as } \\
\text { equally } \\
\text { Chinese } \\
\text { and } \\
\text { Western; } \\
\text { return visit } \\
\text { increases } \\
\text { Chinese }\end{array}$ & $\begin{array}{l}\text { Identify as } \\
\text { Western; } \\
\text { return visit } \\
\text { increases } \\
\text { Chinese } \\
\text { attachment }\end{array}$ & $\begin{array}{l}\text { Identify as } \\
\text { Western/ } \\
\text { equally } \\
\text { Chinese and } \\
\text { Western; } \\
\text { return visit has } \\
\text { no impact on } \\
\text { identity/place }\end{array}$ & $\begin{array}{l}\text { Varied pre- } \\
\text { trip identity; } \\
\text { return visit } \\
\text { results in } \\
\text { less } \\
\text { attachment } \\
\text { to Chinese }\end{array}$ \\
\hline
\end{tabular}




\begin{tabular}{|c|c|c|c|c|c|}
\hline & & attachment & & attachment & identity \\
\hline $\begin{array}{l}\text { Migration } \\
\text { history }\end{array}$ & $\begin{array}{l}\text { New migrants; } \\
\text { migrated as } \\
\text { adults for } \\
\text { life-style or } \\
\text { political } \\
\text { reasons }\end{array}$ & $\begin{array}{l}\text { Long } \\
\text { migration } \\
\text { histories }\end{array}$ & $\begin{array}{l}\text { Long } \\
\text { migration } \\
\text { histories }\end{array}$ & $\begin{array}{l}\text { Varied } \\
\text { migration } \\
\text { histories but } \\
\text { often multiple } \\
\text { migrations and } \\
\text { forced to leave } \\
\text { China }\end{array}$ & $\begin{array}{l}\text { Varied, but } \\
\text { often } \\
\text { multiple or } \\
\text { long } \\
\text { migration } \\
\text { histories }\end{array}$ \\
\hline $\begin{array}{l}\text { Cultural } \\
\text { identity }\end{array}$ & $\begin{array}{l}\text { Chinese or } \\
\text { mostly Chinese }\end{array}$ & $\begin{array}{l}\text { Equal } \\
\text { Chinese } \\
\text { and } \\
\text { Western }\end{array}$ & $\begin{array}{l}\text { Western or } \\
\text { mostly } \\
\text { Western }\end{array}$ & $\begin{array}{l}\text { Equally } \\
\text { Chinese and } \\
\text { Western } \\
\text { Or } \\
\text { Western or } \\
\text { mostly } \\
\text { Western }\end{array}$ & Varied \\
\hline $\begin{array}{l}\text { Initial place } \\
\text { attachment }\end{array}$ & To China & $\begin{array}{l}\text { To China } \\
\text { and North } \\
\text { America }\end{array}$ & $\begin{array}{l}\text { To China and } \\
\text { North America }\end{array}$ & $\begin{array}{l}\text { To North } \\
\text { America }\end{array}$ & Varied \\
\hline $\begin{array}{l}\text { Change } \\
\text { attachment } \\
\text { to China }\end{array}$ & Increase & Increase & Increase & No change & Decrease \\
\hline Motive & Retain ties & Quest & Roots-seeking & Leisure & $\begin{array}{l}\text { Varied: } \\
\text { Obligation / } \\
\text { business }\end{array}$ \\
\hline Perception & Insiders & $\begin{array}{l}\text { Outsiders } \\
\text { seeking to } \\
\text { be insiders }\end{array}$ & Outsiders & Outsiders & Outsiders \\
\hline $\begin{array}{l}\text { Return } \\
\text { destination }\end{array}$ & $\begin{array}{l}\text { Ancestral home } \\
\text { as main } \\
\text { destination }\end{array}$ & $\begin{array}{l}\text { Both China } \\
\text { and } \\
\text { ancestral } \\
\text { home }\end{array}$ & $\begin{array}{l}\text { Both China } \\
\text { and ancestral } \\
\text { home }\end{array}$ & $\begin{array}{l}\text { China as main } \\
\text { destination }\end{array}$ & $\begin{array}{l}\text { Both China } \\
\text { and ancestral } \\
\text { home }\end{array}$ \\
\hline $\begin{array}{l}\text { Return } \\
\text { frequency }\end{array}$ & Frequent & Varied & Varied & Occasional & Varied \\
\hline $\begin{array}{l}\text { Length of } \\
\text { stay }\end{array}$ & Long & Varied & Varied & Short & Short \\
\hline
\end{tabular}

\subsection{Re-affirmative diaspora tourist}

Re-affirmative diaspora tourists identify themselves strongly as being Chinese and view the trip to China as a chance to maintain their existing strong sense of attachment or to increase their sense of Chineseness. In many ways, their experiences are typical of the 
types of experiences reported in previous home return studies. All are first generation migrants who migrated as adults. Their migration histories varied and often reflected reactive migration associated with enduring difficulties. For example both Lenard and Chandler left after the Civil war. Lenard said "I moved to Taiwan just after China's Civil War...and could not return until twenty years later" and Chandler added "I illegally immigrated to HK in 1976, then I came to the US in 1980. I had a very tough time during my early period of immigration... I will never forget the truth that I was forced to leave my hometown".

The home ties maintained by these individuals are strong and close. They clearly define themselves as Chinese or mainly Chinese and more importantly, their place attachments reflect a collective dimension of being "insiders" of the local community. For example, Frankie's expression of his self-identity is typical when he stated "[even after] 30 years of living in the US, I still feel I am Chinese more than American. China is my homeland instead of America". With these strong ties, they reported making frequent return visits. Their return experiences were described as akin to "going home", "being warmly welcomed", "enjoying visiting friends and relatives" and very much feeling still "a part of the community". For them, return travel is closely associated with retaining and re-affirming connections. Enjoyable return travel experience has greatly enhanced their sense as "insiders". With each trip, their home attachment grows stronger. Sabrina's comments are typical, for when she returns to Jiangmen, she is welcomed by Jiangmen Overseas Chinese Office and her Chinese attachment grows:

"My communication with various parties is simple and pleasant here. I am very impressed by Jiangmen officials each time I return... the way they treat overseas Chinese like us... I would regard it as a kind of friendship."

\subsection{Quest diaspora tourist}

The quest diaspora tourist reported stronger attachment to China and/or an increased sense of Chineseness after the trip. But they differ from the other four types in many key areas. To begin, they all had long migration histories that can be traced back to the period of the 1860s to the early 1900s. They were their family's second to the sixth generation in North America. Even so, they felt comfortable in both worlds, identifying themselves as being equally Chinese and Western, coming in part from early exposure to Chinese 
culture as children, receiving a traditional Chinese family education or attending Chinese language schools. Many also reported some confusion about their cultural identity when they were young, like Waldo ( $4^{\text {th }}$ generation Chinese-Canadian) who was one of the ten ethnic minority students in class and grew up in a very traditional Chinese family. Others had a clear identity, like Kaley ( $3^{\text {rd }}$ generation Chinese-Canadian) who stated no confusion about her identity and considered herself as "a Canadian with very strong Chinese characteristics".

While their direct ties to China were tenuous at best, they still felt a spiritual connection with it, which helped draw them back. Sometimes the ties were familial, as Kaley noted "I was strongly influenced by my father, who had strong attachments to China and Chinese culture... I feel I would not have learnt Mandarin or went to Beijing Language University if my father hadn't been such a strong influence." Other times they were more subtle, as evidenced by Melvin ( $5^{\text {th }}$ generation Chinese-American), "my families' attachment is more from a spiritual or cultural perspective". They assimilated with the host society as generations passed.

Their return visit represents a personal quest to look for an imaginary, ideal or romantic China, to develop, discover or re-capture a cultural and spiritual connection. When they were back, they were impressed with feelings of being "a member of the majority rather than minority". But having stated this, they also felt like "outsiders" in the places they visited, even though their quest was to become "insiders" through their trips. Their return travel was mostly pleasant with different extent of communication with their roots, home culture, and local community. For Martin ( $6^{\text {th }}$ generation Chinese-American), the return trip to his grandfather's village helped him "realize his Chinese heritage and figure out where his roots are". He stated that:

[After the trip] I started identifying who I am as a person, who I am to the culture, and to the society... That trip allowed me to become more thoughtful about what my family heritage really was. I wanted to know more about China and explore more about my family history. So I really feel that it would be nice for me to go back to visit my grandmother's village as well as my mother's village.

Effective interaction with local community, well-planned schedule, and opportunity of witnessing the changes in China or/and hometown emerged as being significant to their 
return experience and the level of increase in Chinese attachment.

\subsection{Reconnected diaspora tourist}

The reconnected diaspora tourist feels a strong Western identity before their trip, but has positive post-return changes in their sense of Chinese attachment. They were multi-generational Chinese immigrants with long migration histories. Despite the small size of this group, their distinguished characters differentiated them from the other groups. First, they displayed both generational and spatial distance between themselves and their ancestral roots. For Mr. He ( $3^{\text {rd }}$ generation Chinese-Canadian), his distance to ancestral home was from both perspectives, for his grandfather migrated to Canada in 1919 and he was born in Macau. He feels his current residence in North America is his genuine home. Second, Western culture was identified as their primary cultural identity. Like Clive $\left(5^{\text {th }}\right.$ generation Chinese-American) believed that "my core values were very Western, and I thought and behaved like an American rather than like a Chinese".

For these individuals, their return trip represented a chance to discover their roots and a more generic Chinese identity, rather than to establish a specific ancestral home identity. Interestingly, they all reported having multiple return experiences, through which they witnessed the changes made by China. Their return experiences were rich and pleasant and their Chinese attachments increased critically. Though they saw themselves as "outsiders", they felt "welcomed" and "comfortable" in their home community. Clive and Tam $\left(5^{\text {th }}\right.$ generation Chinese-American) understood some Cantonese and their spouses both helped them communicate with the local community when they returned. The trips back to China were highly valued as significant family events, for it served to reconnect them to their Chinese heritage by increasing their Chinese attachment. Clive commented on his two return trips, as unforgettable event that has totally changed his thoughts about China and about himself:

It is very important to know our history. Our Asian community does that [seek family roots] a lot more. We like to trace the history all the way back. We honor our background, especially Chinese. For me, it is very important to go back and have a better connection to the Chinese heritage. I am sure my return visits affect my attachment to my ancestral hometown. By going there, I can actually see in person rather than just imagine how things happened. The return visits gave me a much more 
solid understanding of where and what kind of family I was set up with.

\subsection{Distanced diaspora tourist}

The return visits conducted by the Distanced diaspora tourists resulted in no change in either their cultural identity or place attachment. They have the most varied migration histories. Most have long generational distance tracing their ancestors' migration to the Gold Rush period. Others with short migration history typically had multiple migration experiences. Yin ( $1^{\text {st }}$ generation Chinese-American), for example, was born in Hong Kong to mainland Chinese parents and then moved to the United States with his family at six. Hong Kong was perceived as his hometown instead of ancestral home village in Kaiping. All these individuals identified themselves as either equally Chinese/Western or mostly Western. Many reported having multiple place attachments that did not necessarily include ties to China. Unlike the groups mentioned previously, they felt no great desire to discover their Chinese origins, although they were interested in learning about the country.

They are labelled the "Distanced" group because they clearly stated a sense of distance between themselves and their ancestral home. To them, China is not their home, but an interesting place to visit. For example, when Mary $\left(2^{\text {nd }}\right.$ generation Chinese-Canadian) talked about her ancestral home, she said "I don't know if I feel attached. I don't know if it is my home". Cara ( $4^{\text {th }}$ generation Chinese-Canadian) said that "I don't feel a kind of attachment. We have so many generations here in Canada and it is my birth place too. My ties are here". Their trip had more to do with taking a vacation, doing a business, or attending a local event rather than finding out about themselves or connecting to their roots. As a result, they tended to visit China's main tourism destinations. When they returned to their ancestral homes, they felt like "outsiders" and also felt the local community saw them as "outsiders". Their complex sense of place, weak Chinese ties, and inability to communicate with the local community were mentioned as significant factors that have directly affected their return experiences. Seth ( $4^{\text {th }}$ generation Chinese American) had a typical experience:

It was important for me to reconnect to my Chinese heritage physically, but doing so did not change my place attachment... It is good to meet some of the people I am

related to. But since it has been many generations, it becomes very difficult to 
maintain the connection. I feel the connection is so distant and I don't feel any more connected actually.

\subsection{Detached diaspora tourist}

The detached diaspora tourist is defined by a diminished sense of attachment to China as a result of their visits. Though members of this group have different personal backgrounds, their return commonly led to a decrease in sense of attachment to China. The reason to migrate and generational distance were important. For example, in Daisy's ( $4^{\text {th }}$ generation Chinese-Canadian) case, her great-grandfather migrated to Canada as a high-level government official and chose not to live in Chinatown, which "helped the whole family evolve from traditional Chinese to more Westernized during 100 years". Multiple migration histories and strong ties to family's first migration destination were relevant to Ellen ( $1^{\text {st }}$ generation Chinese-American). In her case, the family first moved to Taiwan before her eventual settling down in the United States. She felt very close to Taiwan and many of her relatives were still living there.

Interestingly, though, most identify themselves as ethnically Chinese, but not necessarily culturally Chinese. When they were in China, they felt like "outsiders" or "have nothing in common with the people they met", and also felt others saw them as "outsiders". For instance, Ellen who preferred the "frozen" traditional Chinese culture in America, considered herself as "split between Chinese, Taiwanese and American".

Making home return visits was driven more by obligation more so than voluntary choice, as Ellen noted when she travelled "only because she wanted to accompany her parents and husband". Their return experiences were associated with language barriers, unpleasant experiences, poor interaction with local community, and repetitive return activities, all of which have resulted in a decrease in Chinese attachment. Daisy explained why she felt a decrease in her Chinese attachment:

We don't speak Chinese, we don't speak Cantonese. We realized that you couldn't go if you don't speak the language. Because you don't know who you are meeting, and what kind of relation they are to you, and what will happen. Of course, nothing bad will happen but they will mislead... We didn't have good experiences [in China] and I don't think we will go again. People said that there were a lot of people in China who 
don't like overseas Chinese. I kind of feel that way too.

\section{Discussions and conclusion}

This study identified five types of diaspora tourists through examining the impact that home return travel has on one's cultural identity and sense of place. This study extends research into this subject area both conceptually and empirically by looking at different generations of migrants, their migration histories and return experiences. Whereas most of the published work in the tourism literature tends to regard diasporas as being undifferentiated, and also considers only recent migrants (Lew \& Wong, 2004; Kang \& Page, 2000), this study adopts a much broader perspective. The Re-affirmative diaspora tourists correspond with those identified in most of the existing research (McCain \& Ray, 2003; Nguyen \& King, 2004; Kim \& Stodolska, 2013). However, this study suggests they represent just one of five types of diaspora tourist, challenging such rudimentary thinking by presenting a more complete understanding of the complex and nuanced relationship that exists between migration, cultural identity, diaspora tourism and place attachment. Findings of the present research have several significant implications. The demographic features, family migration background, cultural identity, travel behavior and outcomes of return travel varied significantly among the five groups. Migration history as a cause, one's cultural identity and place attachment as consequences of migration history, all contribute to the differences of each group of diaspora tourists.

Place attachment and cultural identity are confirmed as dynamic concepts with multiple dimensions that are influenced by a range of antecedent factors, e.g. the individual's perception of his or her cultural identity prior to the return trip, motives to return and resultant experiences (Gustafson, 2006; Hay, 1998; McHugh \& Mings, 1996). Indeed, how much a trip influences the individual is influenced to a large extent by how close they feel their personal, group and spiritual ties are to their ancestral place. In turn, these feelings were informed in large part by their own family's migration histories, reasons to migrate, the maintenance of direct ties, whether they also felt attached to another place other than either China or North America and their return experience. These conditions influenced both their sense of feeling like insiders or outsiders while in China, and perhaps, most importantly, their underlying reasons to travel. 
As a result, the motives for return travel vary significantly among the five cohorts, with only one group, the Re-affirmative tourist, seeking to retain connections to their ancestral home. While searching for one's roots was evident in two other groups, the underlying motives between the Quest and Reconnected tourists were quite different. One sought to connect to an imaginary China, while the other sought to reconnect with their real ancestral home. The Distanced group travelled primarily for leisure, while the Detached group traveled out of obligation. Neither felt a strong attachment to China, and indeed, in the case of the Detached cohort, reported that the return trip diminishes their sense of attachment.

Practically, the five identified market segments enrich the knowledge about current diaspora tourism market in China. The Chinese tourism market seems to appreciate the Re-affirmative and part of the Quest and Reconnected diaspora tourists in market promotion and product development. For example, the Overseas Chinese Affairs Office in State Council (OCAO) organizes a series of overseas Chinese events to attract the return of recent Chinese migrants who have short migration history and still connect to the homeland. The diversity of the Chinese diaspora tourism market reported by this study requests an innovation in supply of tourism products by diaspora tourism destinations to satisfy all identified segments particularly the overlooked Distanced and Detached groups. Understanding why they return and how they feel after return would be beneficial for Chinese tourism providers to achieve these visitors' travel satisfaction.

Diaspora tourism will continue to be world's significant phenomenon under globalization and growing mobility. This study provides a starting point of segmenting diaspora tourism market. More future research on other diasporic communities is called for to recognize difference/similarity in travel patterns and other characteristics. Moreover, how place attachment affects diaspora travel should also be explored to complete the dynamic process of place-mobility interaction.

\section{References:}

Atkinson, R., \& Flint, J. (2001). Accessing hidden and hard-to-reach populations: Snowball research strategies. Social research update, 33(1), 1-4.

Basu, P. (2005). Roots tourism as return movement: semantics and the Scottish diaspora. In M. Harper (Ed.), Emigrant homecomings: The return movement of emigrants, 1600-2000 (pp. 131-150). Manchester: Manchester University Press.

Basu, P. (2007). Highland Homecomings: Genealogy And Heritage Tourism in the Scottish Diaspora. New York: Routledge. 
Beckley, T. S. (2003). The relative importance of socio-cultural and ecological factors in attachment to place. In L. E. Kruger (Ed.), Understanding community - Forest relations (pp. 105-126). Portland, Oregon: Department of Agriculture, Forest Service, Pacific Northwest Research Station.

Berry, J. W., \& Kalin, R. (1995). Multicultural and ethnic attitudes in Canada: An overview of the 1991 National Survey. Canadian Journal of Behavioural Science/Revue canadienne des sciences du comportement, 27(3), 301.

Berry, J. W. (1997). Immigration, acculturation, and adaptation. Applied psychology, 46(1), 5-34.

Berry, J. W. (2000). Sociopsychological costs and benefits of multiculturalism. In J. Dacyl \& C. Westin (Eds.), Governance of cultural diversity (pp. 297-354). Stockholm: UNESCO.

Bolan, M. (1997). The mobility experience and neighborhood attachment. Demography, 34(2), 225-237.

Boyatzis, R. E. (1998). Transforming qualitative information: Thematic analysis and code development. Sage.

Bruner, E. (1996). Tourism in Ghana: The Representation of Slavery and the Return of the Black Diaspora. American Anthropologist, 98(2), 290-304.

Butler, R. (2003). Relationships between Tourism and Diasporas Influences and Patterns. Espace, populations, sociétés, 21(2), 317-326.

Castles, S. (2000). International Migration at the Beginining of the Twenty-First Century: Global Trends and Issues. International Social Science Journal, 52(165), 269-281.

Chang, I. (2004). The Chinese in America: A narrative history. London: Penguin Books.

Charmaz, K., \& Belgrave, L. (2002). Qualitative interviewing and grounded theory analysis. The SAGE handbook of interview research: The complexity of the craft, 2002.

Chen, S. X., Benet-Martínez, V., \& Bond, H. M. (2008). Bicultural Identity, bilingualism, and psychological adjustment in multicultural societies: immigration-based and globalization-based acculturation. Journal of personality, 76(4), 803-838.

Cohen, E. (1988). Authenticity and commoditization in tourism. Annals of Tourism Research, 15(3), 371-386.

Cohen, R. (1997). Global Diasporas. London: Routledge.

Coles, T., \& Timothy, D. J. (2004). Tourism, Diasporas and Space. London: Routledge.

Con, H., \& Wickberg, E. (1982). From China to Canada: A history of the Chinese communities in Canada. Toronto: McClelland and Stewart Limited.

Cuba, L., \& Hummon, D. M. (1993). Constructing a sense of home: Place affiliation and migration across the life cycle. In Sociological forum (Vol. 8, No. 4, pp. 547-572). Kluwer Academic Publishers-Plenum Publishers.

Daniels, R. (1990). Coming to America: a history of immigration and ethnicity in American life. New York: Harper Collins.

Davidson, A. P., \& Eng, K.-P. K. (2008). Introduction: Diasporic memories and identities. In K.-P. K. Eng \& A. P. Davidson (Eds.), At home in the Chinese diaspora: Memories, identities and belonging (pp. 1-12). Houndmills, England, and New York, NY: Palgrave Macmillan.

Duval, D. T. (2004). Linking return visits and return migration among Commonwealth Eastern Caribbean migrants in Toronto. Global Networks, 4(1), 51-67.

Fourie, J., \& Santana-Gallego, M. (2013). Ethnic reunion and cultural affinity. Tourism Management, 36, 411-420.

Franklin, A., \& Crang, M. (2001). The Trouble with Tourism and Travel Theory. Tourist Studies, 1(1), 5-22. 
Gieryn, T. F. (2000). A space for place in sociology. Annual Review of Sociology, 26, 463-496.

Government of Canada. (2012). Facts and Figures 2011. Citizenship and Immigration Canada. $\quad$ Retrieved 7 May, 2013, from http://www.cic.gc.ca/english/resources/statistics/menu-fact.asp

Guest, G., Bunce, A., \& Johnson, L. (2006). How many interviews are enough? An experiment with data saturation and variability. Field Methods, 18(1), 59-82.

Gustafson, P. (2001). Roots and Routes Exploring the Relationship between Place Attachment and Mobility. Environment and behavior, 33(5), 667-686.

Gustafson, P. (2006). Place attachment and mobility. In N. McIntyre \& K. E. McHugh (Eds.), Multiple dwelling and tourism: Negotiating place, home and identity (pp. 17-31): CAB International.

Gustafson, P. (2009). Mobility and territorial belonging. Environment and Behavior, 41(4), 490-509.

Hall, R. E. (2000). The racial canons of American sociology: Identity across the lifespan as biracial alternative. The American Sociologist, 31(1), 86-93.

Handley, F. J. (2006). Back to Africa: Issues of hosting 'Roots' tourism in West Africa. In J. Haviser \& K. MacDonald (Eds.), African re-genesis: Confronting social issues in the diaspora (pp. 20-31): Left Coast Press, Inc.

Hannerz, U. (1992). Cultural complexity: Studies in the social organization of meaning. Columbia University Press.

Hay, R. (1998). Sense of place in developmental context. Journal of Environmental Psychology, 18(1), 5-29.

Hollinshead, K. (2004). Tourism and third space populations. The restless motion of diaspora peoples. In T. Coles \& D. J. Timothy (Eds.), Tourism, Diasporas and Space. London: Routledge.

Hsieh, H.-F., \& Shannon, S. E. (2005). Three approaches to qualitative content analysis. Qualitative health research, 15(9), 1277-1288.

Hughes, H., \& Allen, D. (2010). Holidays of the Irish diaspora: the pull of the 'homeland'?. Current Issues in Tourism, 13(1), 1-19.

Jameson, D. A. (2007). Reconceptualizing cultural identity and its role in intercultural business communication. Journal of Business Communication, 44(3), 199-235.

Kang, S. K.-M., \& Page, S. J. (2000). Tourism, migration and emigration: travel patterns of Korean-New Zealanders in the 1990s. Tourism Geographies, 2(1), 50-65.

Kearney, M. (1995). The local and the global: The anthropology of globalization and transnationalism. Annual review of anthropology, 547-565.

Kemp, C., \& Chang, B. J. (2004). China. In C. Kemp \& L. A. Rasbridge (Eds.), Refugee and immigrant health: A handbook for health professionals (pp. 132-141). Cambridge: Cambridge University Press.

Kim, J., \& Stodolska, M. (2013). Impacts of diaspora travel on ethnic identity development among 1.5 generation Korean-American college students. Journal of Tourism and Cultural Change, 11(3), 187-207.

Kuzel, A. (1992). Sampling in qualitative inquiry. In B. Crabtree \& W. Miller (Eds.), Doing qualitative research (pp. 31-44). Newbury Park, CA: Sage.

Lee, E. (2003). At America's gates: Chinese immigration during the exclusion era, 1882-1943. Chapel Hill: University of North Carolina Press.

Lew, A., \& Wong, A. (2004). Sojourners, guanxi and clan associations: social capital and overseas Chinese tourism in China. In T. Coles \& D. J. Timothy (Eds.), Tourism, Diasporas and Space. New York: Routledge.

Lewis, R. (2009). The North Carolina Gold Rush. North Carolina: A Digital History 
Retrieved

Li, P. S. (1998). Chinese in Canada. Toronto; Oxford: Oxford University Press.

Light, I. (1984). Immigrant and ethnic enterprise in North America. Ethnic and Racial Studies, 7(2), 195-216.

Lincoln, Y. S., \& Guba, E. G. (1985). Naturalistic inquiry. Beverly Hills, CA: Sage Publications.

Low, S. M., \& Altman, I. (1992). Place attachment: A conceptual inquiry. In I. Altman \& S. M. Low (Eds.), Place attachment (pp. 1-12). New York \& London: Plenum Press.

Marcus, G. E., \& Fischer, M. M. J. (1986). Anthropology as Cultural Critique: An Experimental Moment in the Human Sciences. Chicago: University of Chicago Press.

Massey, D. (1994). Space, place and gender. Cambridge: Polity.

McCain, G., \& Ray, N. M. (2003). Legacy tourism: The search for personal meaning in heritage travel. Tourism Management, 24(6), 713-717.

McHugh, K. E., \& Mings, R. C. (1996). The circle of migration: Attachment to place and aging. Annuals of the Association of American Geographers, 86(3), 530-550.

Mei, W., Zhang, G., Zhang, Y., Guo, J., Guan, F., Gang, H., \& Dai, Y. (2001). The History of Wuyi Overseas Chinese (Vol. 1). Guangzhou: Guangdong Gaodeng Jiaoyu Chubanshe.

Miles, M. B., \& Huberman, A. M. (1994). Qualitative data analysis: An expanded sourcebook (2nd ed.). Thousand Oaks, CA: Sage.

Moufakkir, O. (2011). Diaspora tourism: Using a mixed-mode survey design to document tourism behavior and constraints of people of Turkish extraction resident in Germany. Journal of Vacation Marketing, 17(3), 209-223.

Nguyen, T.-H., \& King, B. (2004). The culture of tourism in the diaspora: The case of the Vietnamese community in Australia. In T. Coles \& D. J. Timothy (Eds.), Tourism, diasporas and space. London: Routledge.

OCAO. (2008). The official website of Guangdong OCAO. Retrieved Jun 3rd, 2009, from http://www.gdoverseaschn.com.cn.

Ostrowski, S. W. (1991). Ethnic tourism - focus on Poland. Tourism Management, 12(2), 125-130.

Pan, L. (1994). Sons of the yellow emperor: A history of the Chinese diaspora. Kodansha International New York.

Pan, L. (1998). The Encyclopedia of the Chinese Overseas Chinese. Singapore: Chinese Heritage Centre.

Pearce, P. L. (2012). The experience of visiting home and familiar places. Annals of Tourism Research, 39(2), 1024-1047.

Pinho, P. (2008). African-American roots tourism in Brazil. Latin American Perspectives, 35(3), 70-86.

Reynolds, T. (2010). Transnational family relationships, social networks and return migration among British-Caribbean young people. Ethnic and Racial Studies, 33(5), 797-815.

Richards, S. L. (2005). What Is to Be Remembered?: Tourism to Ghana's Slave Castle-Dungeons. Theatre Journal, 57(4), 617-637.

Ringel, N. B., \& Finkelstein, J. C. (1991). Differentiating neighborhood satisfaction and neighborhood attachment among urban residents. Basic and Applied Social Psychology, 12(2), 177-193.

Safran, W. (1991). Diasporas in Modern Societies: Myths of Homeland and Return. 
Diaspora, 1(1), 83-99.

Santos, C. A., \& Yan, G. (2010). Genealogical tourism: A phenomenological examination. Journal of Travel Research, 49(1), 56-67.

Scannell, L., \& Gifford, R. (2010). Defining place attachment: A tripartite organizing framework. Journal of Environmental Psychology, 30(1), 1-10.

Shamsuddin, S., \& Ujang, N. (2008). Making places: The role of attachment in creating the sense of place for traditional streets in Malaysia. Habitat International, 32(3), 399-409.

Skeldon, R. (1996). Migration from China. Journal of International Affairs, 49(2), 434-455.

Stedman, R. C. (2006). Understanding place attachment among second home owners. American behavioral scientist, 50(2), 187-205.

Stefansson, A. H. (2004). Homecomings to the future: from diasporic mythographies to social projects of return. Lanham: Lexington Books.

Stephenson, M. L. (2002). Traveling to the Ancestral Homelands: the Aspirations and Experiences of a UK Caribbean Community. Current Issues in Tourism, 5(5), 378-425.

Strauss, A., \& Corbin, J. (1998). Basics of qualitative research: Techniques and procedures for developing grounded theory. Thousand Oaks; London: Sage.

Sussman, N. M. (2000). The dynamic nature of cultural identity throughout cultural transitions: why home is not so sweet. Personality and Social Psychology Review, $4(4), 355-373$.

Tajfel, H. (1981). Human groups and social categories. Cambridge: Cambridge University Press.

Tan, C. B. (2013). Routledge handbook of the Chinese diaspora. London: Routledge.

Timothy, D. J. (2008). Genealogical mobility: Tourism and the search for a personal past. In D. J. Timothy \& J. K. Guelke (Eds.), Geography and genealogy: Locating personal pasts (pp. 115-136). Aldershot; Burlington: Ashgate Publishing.

Tuan, Y.-F. (1974). Space and place: Humanistic perspective. Progress in Geography, 6, 233-246.

Uriely, N. (2010). "Home" and "Away" in VFR Tourism. Annals of Tourism Research, 37(3), 854-857.

Van den Berghe, P. L. (1994). The quest for the other: Ethnic tourism in San Crist. Seattle: University of Washington Press.

Van der Klis, M., \& Karsten, L. (2009). Commuting partners, dual residences and the meaning of home. Journal of Environmental Psychology, 29(2), 235-245.

Vertovec, S. (1999). Conceiving and researching transnationalism. Ethnic and Racial Studies, 22(2), 447-462.

Vertovec, S. (2001). Transnationalism and identity. Journal of Ethnic and Migration Studies, 27(4), 573-582.

Wang, S., \& Lo, L. (2005). Chinese Immigrants in Canada: Their Changing Composition and Economic Performance1. International Migration, 43(3), 35-71.

Werbner, P. (2004). Theorising complex diasporas: purity and hybridity in the South Asian public sphere in Britain. Journal of Ethnic and Migration Studies, 30(5), 895-911.

Wessendorf, S. (2007). 'Roots migrants': transnationalism and 'return'among second-generation Italians in Switzerland. Journal of Ethnic and Migration Studies, 33(7), 1083-1102.

Williams, D. R., Patterson, M. E., Roggenbuck, J. W., \& Watson, A. E. (1992). Beyond the commodity metaphor: Examining emotional and symbolic attachment to place. Leisure Sciences, 14, 29-46. 
Williams, D. R., \& McIntyre, N. (2001). Where heart and home reside: Changing constructions of place and identity. Paper presented at the Trends 2000: Shaping the future, Dept. of Park, Recreation and Tourism Resources, Michigan State University.

Wilson, K., \& Peters, E. J. (2005). You can make a place for it": Remapping urban First Nations spaces of identity. Environment and Planning D: Society and Space, 23(3), 395-413.

Wilson, R., \& Dissanayake, W. (1996). Introduction: tracking the global/local. In R. Wilson \& W. Dissanayake (Eds.), Global/Local: Cultural Production and the Transnational Imaginary (pp. 1-18). Durham: Duke University Press. 